\title{
Trichoderma parareesei Favors the Tolerance of Rapeseed (Brassica napus L.) to Salinity and Drought Due to a Chorismate Mutase
}

\author{
Jorge Poveda $\mathbb{D}$ \\ Spanish-Portuguese Institute for Agricultural Research (CIALE), Department of Botany and Plant Physiology, \\ University of Salamanca, 37185 Salamanca, Spain; jorgepoveda@usal.es; Tel.: +34-923294500 (ext. 5107)
}

Received: 10 December 2019; Accepted: 9 January 2020; Published: 13 January 2020

check for updates

\begin{abstract}
Both drought and salinity represent the greatest plant abiotic stresses in crops. Increasing plant tolerance against these environmental conditions must be a key strategy in the development of future agriculture. The genus of Trichoderma filament fungi includes several species widely used as biocontrol agents for plant diseases but also some with the ability to increase plant tolerance against abiotic stresses. In this sense, using the species T. parareesei and T. harzianum, we have verified the differences between the two after their application in rapeseed (Brassica napus) root inoculation, with T. parareesei being a more efficient alternative to increase rapeseed productivity under drought or salinity conditions. In addition, we have determined the role that $T$. parareesei chorismate mutase plays in its ability to promote tolerance to salinity and drought in plants by increasing the expression of genes related to the hormonal pathways of abscisic acid (ABA) under drought stress, and ethylene (ET) under salt stress.
\end{abstract}

Keywords: Trichoderma; Brassica napus; chorismate mutase; salinity

\section{Introduction}

Although the demand for food continues to increase year after year, agricultural productivity faces several abiotic stresses (i.e., water limitation, salinity, extreme temperatures) that reduce it, which are often associated with global warming [1]. Abiotic stresses have a negative impact on plant growth, reducing the yield of all the major crops and resulting in considerable losses [2]. Climate change is predicted to be very harmful for agriculture production, particularly at low latitudes in developing countries. In this sense, plants have to adapt to the changing conditions in the environment they grow [3]; therefore, improving plant stress resistance is critical for agricultural productivity and also for environmental sustainability [4].

The most important environmental stress that constrains crop yield is drought. In this sense, more than $40 \%$ of the world is classified as dry land, an area that increases each year due to the increase in the world temperature as a result of global warming [5]. Thus, water is the single most important abiotic factor limiting crop productivity [6]. Therefore, it is estimated that the damage caused by drought in crops will reduce their productivity by $36 \%$ [7], although it can induce a reduction in yield between $13 \%$ and $94 \%$ in several crops, depending on the intensity and duration of the stress [8].

On the other hand, soil salinity is a global problem in crop productivity due to land clearing and unsustainable irrigation practices. To avoid the osmotic damage caused by salt in their roots, and to be able to absorb the water present in the soil, plants must pay a high energy cost. Thus, a reduced yield leads to significant economic damage-up to losses of $33 \%$ of profits for farmers. Moreover, a constant increase in soil salinity may mean that cropping becomes impossible [9].

In this context, improving farming technologies and crop varieties has been the main driver to increase farm productivity during the last century, but, to ensure an environmentally sustainable and 
socially responsible food supply, we need the development of new agricultural practices that focus on minimizing soil degradation, environmental pollution, and the adverse effects of climate change, basically, environmentally friendly biological strategies. In this sense, the soil microbiome has great potential to provide solutions due to its capacity as a driver of soil functions and agricultural crop productivity. The role of microorganisms in plants, particularly those inhabiting the rhizosphere, includes performing core functions such as the supply of nitrogen, phosphorus, potassium, sulphur, and micronutrients. Such host-microbiome interactions are crucial for plant health, as microbes can affect plant growth and/or development at multiple stages, including germination, morphogenesis, flowering, and hence, productivity. Microbial symbionts of plants also act as a functional extension in plant defense against biotic and abiotic stresses [10]. As far as abiotic stress is concerned, beneficial microorganisms are able to counteract environmental stress by improving plant performance, enhancing plant growth and productivity, interacting with several processes involved in plant responses to stress, and increasing the accumulation of antioxidant compounds that allow a decrease in plant stress sensitivity, with interesting results in their application today [8]. Examples of this can be found in the microorganisms' capacity of reactive oxygen species (ROS) scavenging, to provide membrane stability and osmoprotection, to promote stomatal regulation and xylem hydraulic conductance, and to regulate root zone water availability and root ethylene (ET) and abscisic acid (ABA) levels [11,12].

Among the so-called beneficial microorganisms for agriculture, Trichoderma is a genus of soil-borne filamentous fungi that includes species widely used as biocontrol agents in agriculture, which are able to colonize diverse substrates under different environmental conditions. These species stand out for their capacity to antagonize plant pathogens through different mechanisms such as mycoparasitism, antibiosis, competition, and triggering plant defense; however, some strains are also able to stimulate plant growth and induce tolerance to abiotic stress [13-15]. Regarding this last mechanism, in 2010, Mastouri et al. described how the treatment of tomato seeds with T. harzianum accelerates their germination, increases the vigor of the seedlings and reduces the effects caused by thermal, osmotic, saline and water stress, as it would induce physiological changes in the plant against oxidative damage, decreasing the damage caused by the accumulation of ROS that occurs in stressed plants due to the reduced accumulation of lipid peroxides and the production of antioxidant compounds such as glutathione [16]. This was also observed by Ghorbanpour et al. (2018) in tomatoes subjected to low temperatures [17], as well as by Yasmeen and Siddiqui (2018) in corn and rice subjected to salinity [18], and also in tomatoes-with a reduction in stomatal conductance and transpiration, and the expression of increased levels of the genes involved in signaling abscisic acid-, ethylene-, and salicylic acid-dependent pathways [19]. As far as ABA is concerned, it is the crucial plant-hormone in regulating stomatal aperture, which is required to limit water loss from leaves under drought conditions, also, ABA induces the expression of many genes whose products are important for stress responses and tolerance such as enzymes for osmoprotectant synthesis [20]. On the other hand, ET signaling positively regulates salt tolerance, thanks to altering $\mathrm{Na}^{+} / \mathrm{K}^{+}$ratio and selectively activating salt-tolerance genes in plants, such as ETR1, ETR2, EIN4, CTR1, ECIP1, SIED1, ERF1, and/or ESE1 [21].

As far as T. parareesei is concerned, there are very few studies on this strain, so some of its potential applications in agriculture may be yet to be discovered. T. parareesei is considered the ancestor of T. reesei, a common strain used in the biotechnological industry for the production of cellulolytic and hemicellulolytic enzymes [22]. Its genome was annotated by Yang et al. in 2015 [23].

In agriculture applications, T. parareesei has shown biocontrol potential against fungal (Rhizoctonia solani and Botrytis cinerea) and oomycete (Pythium irregularulare) phytopathogens, the promotion of root growth in tomato seedlings, and the induction of tolerance to salinity and resistance against B. cinerea in tomato plants [24]. Continuing this work, Pérez et al., in 2015, determined the key role of the T. parareesei Tparo7 gene, encoding a chorismate mutase (CM), a shikimate pathway branch point leading to the production of aromatic aminoacids, in T. parareesei mycoparasitic capacity against R. solani, B. cinerea and Fusarium oxysporum and its ability to trigger systemic plant defenses by root colonization [25]. 
Considering the need to find new biological strategies to increase agricultural productivity in situations of abiotic stress, in this work, we have inoculated rapeseed or canola (Brassica napus) plants with T. parareesei and induced stress situations with salt and drought. This was undertaken due to the absence of studies with rapeseed and Trichoderma and the search for new plant-beneficial microorganisms not yet studied-such as T. parareesei. On the other hand, rapeseed is the second most important oilseed crop of the world. It is an indispensable component of crop rotations in major growing areas to maintain soil fertility and contributes to sustainable production. Moreover, it contributes to farmers' incomes and, therefore, helps to stabilize rural populations, because rapeseed is a raw material for vegetable oil and extraction meal [26]. Moreover, we have tried to elucidate the possible role of $\mathrm{CM}$ in the ability of the fungus to improve the tolerance of plants against abiotic stress because its relationship with biotic stresses has already been elucidated [25].

\section{Materials and Methods}

\subsection{Plant Material and Growth}

B. napus cv. Jura were the plants used in this study, whose seeds were surface-sterilized by vigorous sequential shaking in $70 \%$ ethanol and $2 \%$ sodium hypochlorite solutions for 10 min each and then washed thoroughly four times in sterile distilled water, as previously described [19].

Seeds were plated on Murashige and Skoog (MS) (Duchefa, Haarlem, the Netherlands) solid medium (agar $1 \%$ ) with sucrose $(1 \%)$ in a growth chamber at $22{ }^{\circ} \mathrm{C}, 40 \%$ relative humidity $(\mathrm{RH})$ and a $16 \mathrm{~h}$ light $/ 8 \mathrm{~h}$ dark photoperiod at $80-100 \mu \mathrm{E} \mathrm{m}^{-2} \cdot \mathrm{s}^{-1}$, for seven days. Rapeseed seedlings were individually transferred to $5 \mathrm{~L}$ pots containing a mixture of peat/vermiculite (3:1) and maintained in a greenhouse at $22 \pm 2{ }^{\circ} \mathrm{C}$ and a $16 \mathrm{~h} \mathrm{light} / 8 \mathrm{~h}$ dark photoperiod, as previously described [27], placed in random trays on the tables (Figure S1) and watered with $2 \mathrm{~L}$ of water to every four pots (a plate) (bottom pot irrigation) every two days.

\subsection{Abiotic Stress and Productivity Quantification}

Regarding saline stress, rapeseed plants were watered with a $200 \mathrm{mM} \mathrm{NaCl}$ solution every two days, starting from the development of the third true leaf (three-week-old plants) until the end of its development cycle (19 weeks). The drought stress was developed due to a progressive reduction in watering from the development of the third true leaf (three-week-old plants). The pots were irrigated twice a week in weeks 4 and 5, once a week in weeks 6 and 7, and once every two weeks until the end of the life cycle (weeks 8-19).

The siliques from 15 rapeseed plants per condition were collected at the end of the life cycle and counted (19 weeks).

\subsection{Trhichoderma Cultures and Inoculation}

T. harzianum CECT 2413 (Spanish Type Culture Collection, Valencia, Spain, referred to as strain T34) and T. parareesei (formerly T. reesei) IMI 113135 (CABI Bioscience, Egham, UK, referred to here as the T6 strain) were used throughout this study. Moreover, we use from the work of Pérez et al. in 2015, the Tparo7-S4 T. parareesei transformant was obtained by the silencing of the Tparo7 gene, together with the transformation control strain Tp-TC with pJL43b1 [25].

Spores were harvested from seven-day-old potato dextrose-agar (PDA, Sigma-Aldrich, Madrid, Spain) dishes as previously described [24], after being grown at $28^{\circ} \mathrm{C}$.

Each plant was inoculated by Trichoderma with $1 \mathrm{~mL}$ of a conidial suspension containing $2 \times$ $10^{7}$ spore $\mathrm{mL}^{-1}$, one week after the seedlings had been transplanted. Twenty plants were used for each condition and inoculant, and each assay was repeated three times, at different times. 


\subsection{Quantification of Trichoderma-Root Colonization and Gene Expression Studies}

For the analyses of fungal root colonization and the expression of abiotic tolerance-related genes, for each condition and inoculant, roots from five plants per each treatment were pooled and root pools from three independent assays were considered. Roots were collected during the formation of the floral primordial, in 10-week-old rapeseed plants [28,29]. All root material was washed with water until there was no remaining substrate, immediately frozen with liquid nitrogen, and pulverized with a mortar.

The quantification of Trichoderma colonization was performed by the quantification of Trichoderma DNA in the roots of rapeseed, by quantitative PCR (qPCR) as previously described [28]. The DNA was extracted from rapeseed roots of T34, T6, Tp-TC and Tparo7-S4 inoculated plants. A mix was prepared in a 10- $\mu \mathrm{L}$ volume using $5 \mu \mathrm{L}$ of Brilliant SYBR Green QPCR Master Mix (Roche, Penzberg, Germany), $10 \mathrm{ng}$ of DNA, the forward and reverse primers at a final concentration of $100 \mathrm{nM}$, and nuclease-free PCR-grade water to adjust the final volume. The Actin genes of Trichoderma and rapeseed were used for the quantification, as in other Trichoderma-rapeseed interaction studies [28,29], and their corresponding primer pairs are indicated in Table 1. Amplifications were performed in an ABI PRISM 7000 Sequence Detection System (Applied Biosystems, Foster City, CA, USA), programmed for 40 cycles under the following conditions: denaturation, $95^{\circ} \mathrm{C}$ for $15 \mathrm{~s}$; annealing, $60^{\circ} \mathrm{C}$ for $1 \mathrm{~min}$; extension, $72{ }^{\circ} \mathrm{C}$ for $1 \mathrm{~min}$. Each PCR was performed in triplicate by using the DNA extracted from three root pools of five plants each-one for each treatment and plant type. Cycle threshold values served to calculate the amount of fungal DNA using standard curves. The values of Trichoderma DNA were referred to the amount of rapeseed DNA in every corresponding sample.

Table 1. Oligonucleotides used in this work.

\begin{tabular}{|c|c|c|c|}
\hline Code & Sequence $\left(5^{\prime}-3^{\prime}\right)$ & Use & Reference \\
\hline Act-T-F & ATGGTATGGGTCAGAAGGA & \multirow{2}{*}{ Endogenous Trichoderma gene } & \multirow{2}{*}{ [29] } \\
\hline Act-T-R & ATGTCAACACGAGCAATGG & & \\
\hline Act-Bn-F & CCCTGGAATTGCTGACCGTA & \multirow{2}{*}{ Endogenous rapeseed gene } & \multirow{2}{*}{ [29] } \\
\hline Act-Bn-R & TGGAAAGTGCTGAGGGATGC & & \\
\hline ACCO1-Bn-F & ATTTTGGGAAGAGATTGGAG & \multirow{2}{*}{ Synthesis gene of ET in rapeseed } & \multirow{2}{*}[30]{} \\
\hline ACCO1-Bn-R & GCTGGATAGTTGCTCACCTTA & & \\
\hline ERF1-Bn-F & AGTCACGGCGTTACAAT & \multirow{2}{*}{ Response gene to ET in rapeseed } & \multirow{2}{*}[31]{} \\
\hline ERF1-Bn-R & GTGGTGACAACGGCGAGAA & & \\
\hline NCED3-Bn-F & GTGGAAGTCGGAGTTACAGATAG & \multirow{2}{*}{ Synthesis gene of ABA in rapeseed } & \multirow{2}{*}{ [32] } \\
\hline NCED3-Bn-R & CCAAGTCACTAGCTCCATAAA & & \\
\hline PYL4-Bn-F & CGGTCCTAACCAGTGTTGCTC & \multirow{2}{*}{ Response gene to $\mathrm{ABA}$ in rapeseed } & \multirow{2}{*}{ [33] } \\
\hline PYL4-Bn-R & GCTGAAACTAATGTCGTGCCTCT & & \\
\hline
\end{tabular}

For gene expression studies, the pooled roots were used for RNA extraction with the TRI reagent (Ambion, Austin, TX, USA), following the manufacturer's instructions. cDNA was synthesized from $2 \mu \mathrm{g}$ of RNA, which was treated with DNase RQ1 (Promega Biotech Ibérica, Alcobendas, Spain), and then used for reverse transcription with an oligo(dT) primer with the Transcriptor First Strand cDNA Synthesis Kit (Takara Bio, Inc., Tokyo, Japan), following the manufacturer's protocol. Gene expression was analyzed by RT-qPCR, using an ABI PRISM 7000 Sequence Detection System with Brilliant SYBR Green QPCR Master Mix (Stratagene, La Jolla, CA, USA). All PCR reactions were performed in triplicate in a total volume of $10 \mu \mathrm{L}$ for 40 cycles under the following conditions: denaturation, $95{ }^{\circ} \mathrm{C}, 30 \mathrm{~s}$; annealing, $60{ }^{\circ} \mathrm{C}, 1 \mathrm{~min}$; extension, $72{ }^{\circ} \mathrm{C}, 1 \mathrm{~min}$. Threshold cycles $\left(C_{\mathrm{T}}\right)$ were determined using the 7000 SDS System Software (Applied Biosystems, Foster City, CA, USA), and $C_{T}$ values were calculated using the rapeseed Actin gene as an endogenous control. The primers used are given in Table 1: genes of the ACC-oxidase 1 (ACCO1), ethylene response factor 1 (ERF1), lipoxygenase 1 (LOX1), 
nine-cis-epoxycarotenoid dioxygenase 3 (NCED3), and ABA-receptor (PYL4). Data are expressed using $2^{-\triangle \Delta C T}$ method [34]. The choice of genes for synthesis and response to ABA and ET is based on the importance of both hormones in the response to abiotic stresses in plants.

\subsection{Indirect Quantification of ROS in Roots}

The indirect quantification of ROS in roots was carried out by measuring electrolyte leakage similar to the method used by Aguilar et al. in 2015 for leaf discs, which really measures cellular oxidative damage related to the production of ROS [35]. From the root pools formed to carry out colonization and gene expression analyses (Section 2.4), $100 \mathrm{mg}$ of fresh tissue was briefly mixed with water and floated on $5 \mathrm{~mL}$ of double-distilled water for $6 \mathrm{~h}$ at room temperature. The conductivity of the water was measured using a Crison ${ }^{\mathrm{TM}}$ Conductimeter GLP31 (Crison, Barcelona, Spain). This represented the electrolyte leakage from the roots (Reading 1). Then, samples were boiled for $20 \mathrm{~min}$ at $90^{\circ} \mathrm{C}$. After the liquid cooled down, the conductivity of the water was measured again. This represented the total ions present in the roots (Reading 2). Electrolyte leakage, an indirect measurement of ROS, was represented as the percentage of total ions released [(Reading $1 /$ Reading 2$) \times 100$ ].

\subsection{Statistical Analysis}

The statistical analysis of the data was carried out using Statistix 8.0 software (Miller Landing $\mathrm{Rd}$, Tallahassee, FL, USA). One-way ANOVA using Tukey's multiple range test at $p<0.05$ was used for pairwise comparisons; the different letters indicate the significant differences. The combined effects of Trichoderma strain T34 and abiotic stress were analyzed by two-way ANOVA followed by Sidak's multiple comparison test, indicating significant differences as follows: ${ }^{*} p<0.05 ;{ }^{* *} p<0.01$; ${ }^{* * *} p<0.001 ;{ }^{* * * *} p<0.0001 ;{ }^{* * * *} p<0.00001$. The GxE interaction was performed following the methodology described by Mondo et al. in 2019 [36]. Using the interactions between rapeseed, different stress conditions, and different inoculations (using both parameters as different environments), we determined the absence of GxE interaction in our study.

\section{Results}

\subsection{Rapeseed Productivity}

Without stress, a significant increase in rapeseed seed yielding in interaction with T6 strain, the transformation control (Tp-TC), and the Tparo7 silenced mutant (Tparo7-S4)—compared with not-inoculated plants-was observed. Furthermore, this increased productivity was even higher after root inoculation with the T34 strain (Figure 1A).

Under drought stress, all the root treatments showed a significantly better yield compared with the un-inoculated plants (control). The highest yield was observed in the root treated by T6 and $\mathrm{Tp}-\mathrm{Tc}$, and the lowest values were observed in the un-treated plants, followed by Tparo7 (Figure 1B). Similar results were observed under salt stress conditions (Figure 1C), although there are no significant differences between inoculation with T34 and with the rest of Trichoderma.

\subsection{Trichoderma-Roots Colonization}

Without stress, the levels of root colonization by T6, Tp-TC, and Tparo7-S4 are significantly lower than in the case of T34 (Figure 2). Under stress due to drought and salinity, the levels of every Trichoderma strains colonization increase significantly in comparation with T34 colonization without stress, being significantly higher still in the case of T6, Tp-TC, and Tparo7-S4 (Figure 2).

\subsection{Expression Levels of Different Hormone-Related Genes}

Rapeseed root colonization by the T34 strain without stress induces higher gene expression in ET-related genes such as ACCO1, involved in ethylene biosynthesis, as is the case with Tparo7-S4, and ERF1—involved in ethylene signaling, compared to rapeseed without inoculation (Figure 3). 
Contrastingly, a significantly lower gene expression in ABA-related genes, such as NCED3 and PYL4, involved in ABA metabolism and action, respectively, was observed (Figure 3). Concerning to ABA-related gene expression, similar results were observed in the rapeseed plants root-inoculated with different $T$. parareesei strains, whereas the higher gene expression of ET-related genes was also observed-although significant differences were only detected in the case of the silenced mutant Tparo7-S4 (Figure 3).

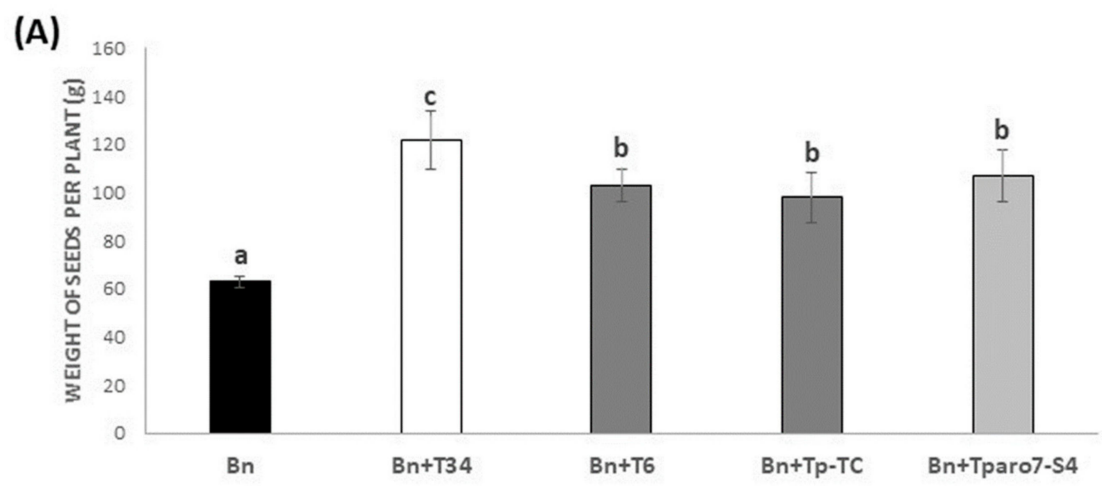

(B)
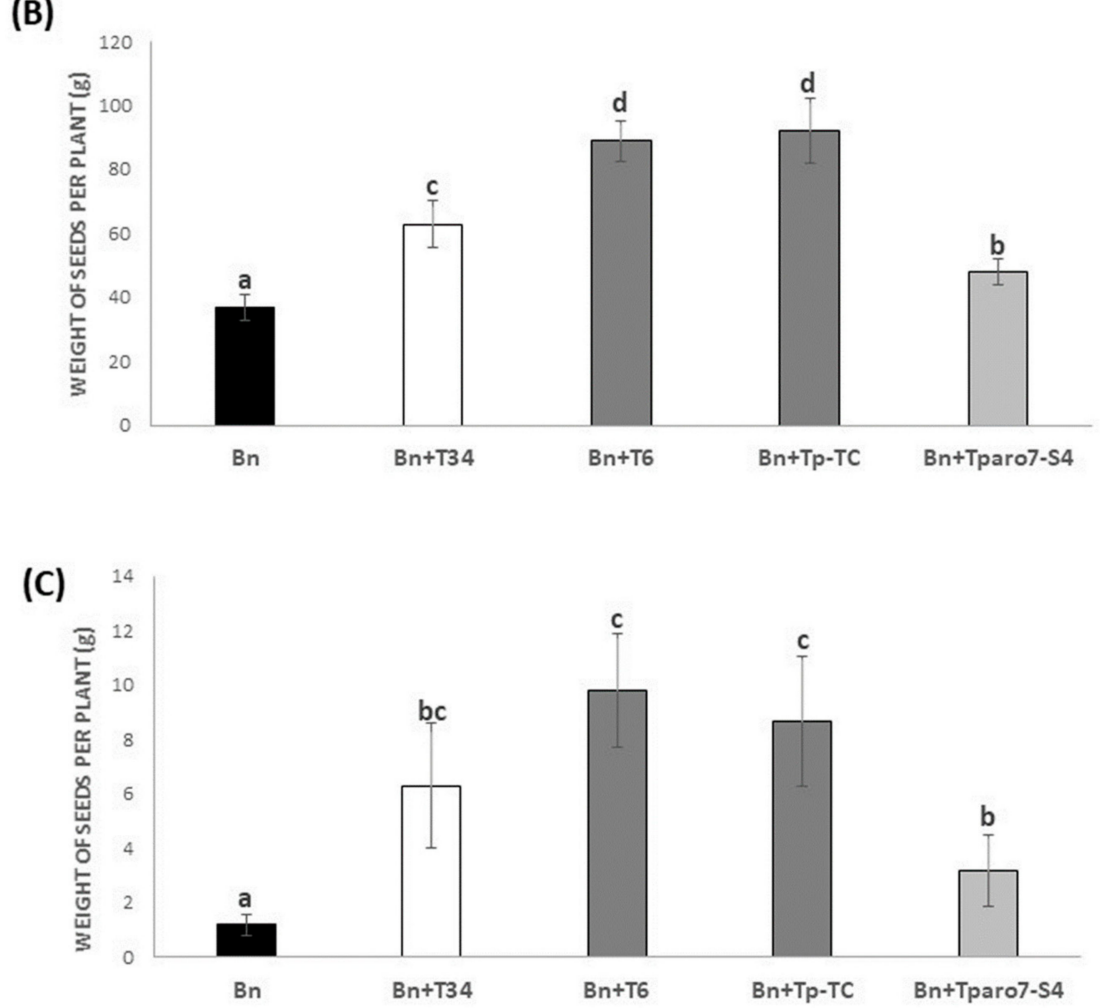

Figure 1. Rapeseed productivity. The weight $(\mathrm{g})$ of the seeds collected from the rapeseed $(\mathrm{Bn})$ and the different Trichoderma inoculations: T. harzianum (+T34), T. parareesei (+T6), T. parareesei transformation control (+Tp-TC), and the transformant with the silenced Tparo7 gene (+Tparo7-S4) per plant without stress (A), under drought stress $(\mathbf{B})$ and under salt stress $(\mathrm{NaCl} 200 \mathrm{mM})(\mathbf{C})$. Data are the mean of three biological replicates for each condition with the corresponding standard deviation, and 15 plants per replicate were used. One-way analysis of variance (ANOVA) was performed, followed by the Tukey's test. Different letters represent significant differences $(p<0.05)$. 


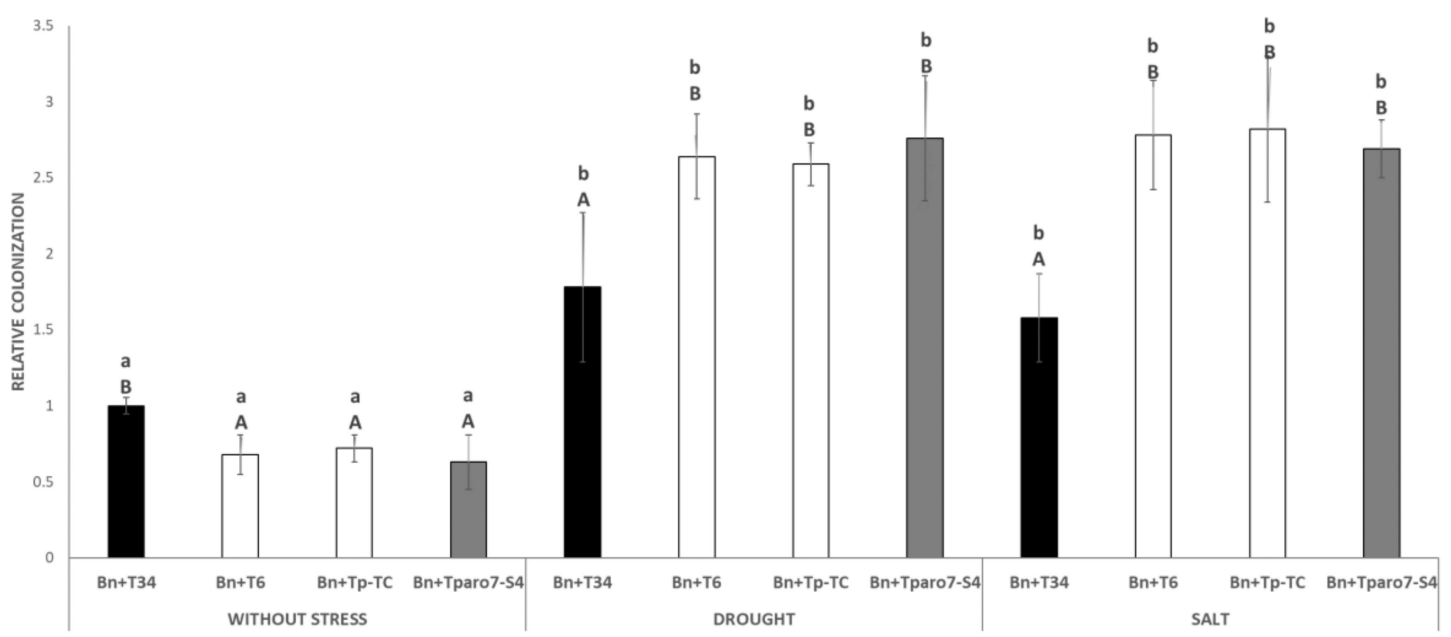

Figure 2. Measurements of rapeseed-root colonization by T. harzianum (+T34), T. parareesei (+T6), T. parareesei transformation control (+Tp-TC), and the transformant with the silenced Tparo7 gene (+Tparo7-S4) without stress, under drought stress and under salt stress ( $\mathrm{NaCl} 200 \mathrm{mM})$. To quantify rapeseed root colonization, the DNA of the fungus was quantified by qPCR from radicular samples using the actin genes from both the plants and the fungus. Fungal DNA/plant DNA ratio was normalized to 1 in the case of T34 and was calculated based on this data for the rest of the situations and inoculants. Data are the mean of three biological replicates for each condition with the corresponding standard deviation, and for each biological replicate and condition, roots from five plants were used. One-way analysis of variance (ANOVA) was performed, followed by the Tukey's test. Different letters represent significant differences $(p<0.05)$, comparing between environment within each treatment (strain)- and control-(identify by small letters) and treatment- and control- (strain) within each specific environment (identify by capital letters). Also, two-way analysis of variance (ANOVA) was performed, shown in Supplementary Table S1.
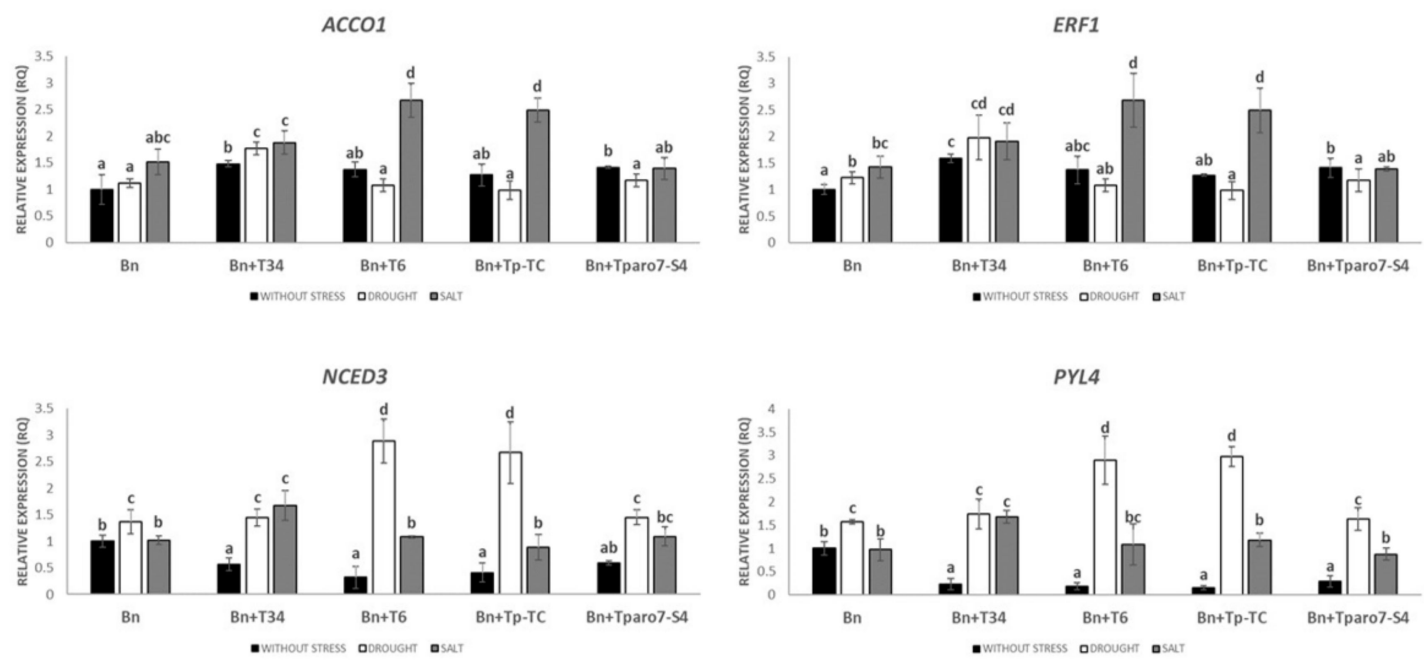

Figure 3. Quantitative reverse transcription polymerase chain reaction (RT-qPCR) analysis of the expression of some tolerance-abiotic-related genes in the roots of rapeseed $(\mathrm{Bn})$ inoculated with $T$. harzianum $(+\mathrm{T} 34)$, T. parareesei $(+\mathrm{T} 6)$, T. parareesei transformation control $(+\mathrm{Tp}-\mathrm{TC})$, and the transformants with the silenced Tparo7 gene (+Tparo7-S4). Values correspond to relative measurements against plants without stress neither Trichoderma-inoculation $\left(2^{-\Delta \Delta \mathrm{Ct}}=1\right)$. Data are the mean of three biological replicates for each condition with the corresponding standard deviation, and for each biological replicate and condition, roots from five plants were used. One-way analysis of variance (ANOVA) was performed, followed by the Tukey's test. Different letters represent significant differences $(p<0.05)$ between plants with and without stress and Trichoderma-inoculation. 
Under abiotic stress conditions, a significantly higher gene expression in the levels of ET-related genes was only observed in rapeseed plants root-inoculated with the T6 and Tp-TC strains under drought conditions, whereas a significantly higher gene expression in ABA-related genes were detected under salt stress conditions in rapeseed plants interacting with T. parareesei strains, except in the case of the silenced mutant $\mathrm{T}$ (Figure 3). In addition, rapeseed root inoculation with T34 also induces the expression of ET-related genes, although this increase is only significant in the case of salt stress. Concerning ABA-related genes, a significantly higher gene expression in the corresponding expression levels was only observed under drought stress conditions.

\subsection{ROS in Roots}

With rapeseed root inoculation with Trichoderma, a significant decrease in the relative leakage of the roots is observed-an indirect measure of oxidative stress by ROS (Figure 4). Under salinity, there is a significant increase in the oxidative stress of rapeseed, which decreases significantly with the application of T34, the application of T6 and Tp-CT being even more beneficial; however, it does not occur with the application of Tparo7-S4. Similar results were observed under drought.

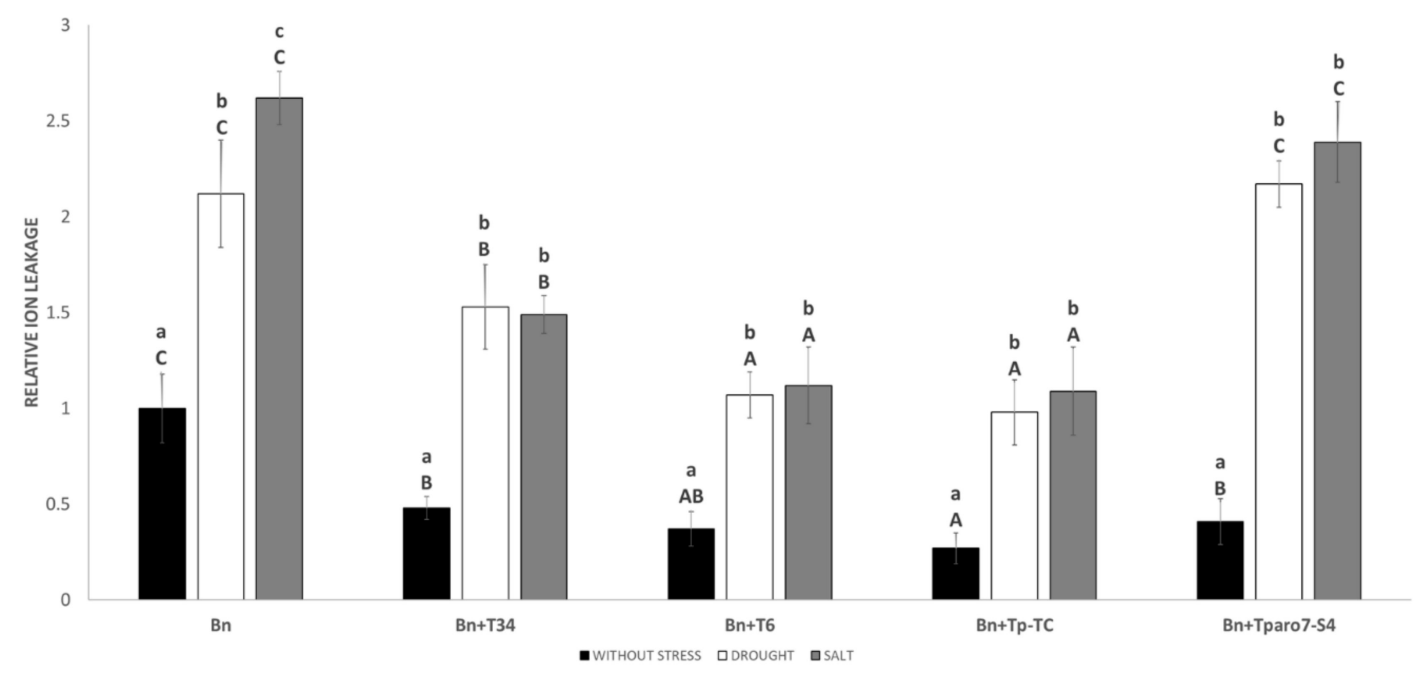

Figure 4. Indirect quantification of ROS in roots by relative ion leakage in the roots of rapeseed $(\mathrm{Bn})$ inoculated with T. harzianum (+T34), T. parareesei (+T6), T. parareesei transformation control (+Tp-TC), and the transformants with the silenced Tparo7 gene (+Tparo7-S4). Data are the mean of three biological replicates for each condition with the corresponding standard deviation, and for each biological replicate and condition, roots from five plants were used. One-way analysis of variance (ANOVA) was performed, followed by the Tukey's test. Different letters represent significant differences $(p<0.05)$, comparing between environment within each treatment (strain)- and control-(identify by small letters) and treatment- and control-(strain) within each specific environment (identify by capital letters). Also, two-way analysis of variance (ANOVA) was performed, shown in Supplementary Table S2.

\section{Discussion}

Rapeseed is important for edible oil production in semi-arid areas, where abiotic stresses threaten its production [37], as observed under salt and drought stress (Figure 1). In this sense, little is known about the transcriptomic changes that occur in rapeseed in response to abiotic stress-particularly salinity and drought [38]. In spite of this, it has been observed how salinity stress provokes an inhibition of seed germination and seedling establishment in rapeseed [39], as well as a reduction in biomass, size, and number of leaves, but not in photochemical activity [40]. Moreover, the way in which drought stress significantly inhibited germination and seedling growth led to oxidative stress from excessive $\mathrm{H}_{2} \mathrm{O}_{2}$ generation and reduced the chlorophyll content [41], resulting in growth inhibition, oil content reduction, and yield loss during the reproductive stage [42]. 
In our study, we have verified how the inoculation without stress of rapeseed plants with different strains of Trichoderma represents a significant increase in the weight of seeds produced by each plant (Figure 1A), something observed previously, although without knowing exactly what are the fungal mechanisms involved in it of all those described for the Trichoderma-plant interaction, with the application of T. harzianum, also increasing the weight of seeds per plant [29]; T. asperellum, with an increase in seed weight, lipid content, and total seed yield [43]; T. viride, increasing fresh and dry biomass [44]; and T. atroviride, with a significantly larger root and shoot biomass, but without a systemic induction of plant-defenses against the caterpillars Plutella xylostella [45]. However, the induction of systemic resistance in rapeseed has been observed with the rapeseed root application of T. harzianum against the leaf fungi Sclerotinia sclerotiorum [46] and Erysiphe cruciferarum [47].

Moreover, the inoculation with T34 increases significantly rapeseed productivity more than T6, Tp-TC and Tparo7-S4 (Figure 1A). It is probably due to the greater capacity of rapeseed root colonization observed in T34 compared to the other fungi (Figure 2). In this sense, the key role of the ThKEL1 protein of T34 has been demonstrated in the colonization of crucifer roots, such as rapeseed and Arabidopsis thaliana, but not in other groups of taxonomically more remote plants, such as tomatoes, due to the modification of their myrosinase activity involved in the hydrolysis of glucosinolates-secondary metabolites present in this group of plants [29]. T. parereesei does not present any homologous gene to Thkel1 in its genome; therefore, the productivity increase observed with T34 could be due to the presence of Thkel1 in its genome, as a consequence of an increase in its ability to root-colonize in crucifers [29].

Under abiotic stresses, little has been studied of the benefits of rapeseed radicular inoculation with beneficial fungi, due to the accumulation of fungicidal allochemicals in its roots [48]. The application of bacteria has resulted in an improvement in the growth, physiology, and antioxidant activity, and reduced the chromium uptake of rapeseed in chromium-contaminated soil by Burkholderia phytofirmans [49]; furthermore, it has improved major seed germination, root length, shoot length, amount of lateral roots, and chlorophyll content in rapeseed seedlings under salt stress by Enterobacter cloacae [50] and Pseudomonas stutzeri [51]. Nonetheless, we have observed how the rapeseed-root-inoculation with Trichoderma also increases its tolerance against drought (Figure 1B) and salinity (Figure 1C) —demonstrated in its productivity. Similarly, an increase in the salt-tolerance was observed with the inoculation of tomatoes with T. harzianum $[16,19]$ and T. parareesei $[24]$, of cucumber with T. harzianum [52], and of wheat with T. longibrachiatum [53,54]; also, regarding drought-tolerance, with the inoculation of tomato with T. longibrachiatum or T. harzianum $[55,56]$ —never before analyzed in the case of rapeseed.

Moreover, the inoculation with $\mathrm{T} 6$ and Tp-TC implies a significant increase in tolerance to abiotic stresses against inoculation with T34 (Figure 1B,C), probably due to the greater capacity for root colonization of $\mathrm{T} 6$ and Tp-CT that we have reported (Figure 2). In this sense, it has been demonstrated how, in situations of abiotic stresses, Trichoderma colonizes the plant's roots to a greater extent, in order to improve the plant's ability to tolerate stress. [57]. On the other hand, the rapeseed-inoculation with Tparo7-S4 under salt or drought stress had the same colonization levels as T6 and Tp-TC (Figure 2), but its ability to increase tolerance was significantly reduced to the levels observed for T34 (Figure 1C) or even lower (Figure 1B), never reaching the productive levels of uninoculated plants. This is due to the presence of the Tparo7 gene in T. pararesei, a chorismate mutase protein/group of proteins implicated in tolerance to salt and drought stress in tomato [58].

Plants under abiotic stresses differentially express a range of genes involved in their tolerance to each stress, and the same can be said for rapeseed plants [59]. Under drought-stress, the key phytohormone in plant tolerance is ABA [60], so it increases the expression of its synthesis and response genes, including its PYL receptors [4] and NCED synthesis gene in rapeseed [32], as we have been able to observe in our study (Figure 3). Meanwhile, ET acts against salt stress [60], although an increase in the expression of the ERF response gene has been observed in both salinity and drought situations in Brassica rapa [61], as we have also observed with rapeseed (Figure 3). 
The ability of Trichoderma to produce ACC-deaminase and prevent the accumulation of ET in the roots $[57,62]$ has been extensively studied. In this sense, the inoculation of rapeseed with T34 under drought stress implies an increase in the expression of ET-related genes, something not observed in other studies, while under salt stress, the ABA-related genes increase, as observed by Contreras-Cornejo et al. (2010) in A. thaliana with the application of T. virens and T. atroviride [63]. In contrast, the inoculation with $\mathrm{T} 6$ and Tp-TC causes a significant increase in the expression of ABA-related genes in drought-stress and of ET-related genes in salt-stress, specific effective responses against both stresses and, therefore, the plants have a higher tolerance [60]. As far as ABA is concerned, the increase in the expression of the genes related to this hormone by inoculation with $\mathrm{T} 6$ and Tp-TC in rapeseed would have a direct relationship with its greater capacity for tolerance against drought, possibly due to plant physiological mechanisms of response to ABA as the regulation of stomatal aperture, key mechanism to limit water loss from leaves under drought conditions, and to induce the osmoprotectant compounds synthesis [20]. On the other hand, the increase in tolerance in rapeseed after inoculation with T6 and Tp-TC under salt stress would be directly related to an increase in the expression of genes related to ET, a hormonal route implied in tolerance against this type of stress thanks to alter $\mathrm{Na}^{+} / \mathrm{K}^{+}$ratio and selectively activating salt-tolerance genes in plants [21].

Moreover, the plant accumulates ROS, which are a strong oxidative stress in the cells [64,65], and have been proven to cope with abiotic stresses such as salinity and drought. We have verified how the application of Trichoderma reduces this type of stress on rapeseed roots (Figure 4), as have other authors with tomato [16], Arabidopsis and cucumber [53], checking how the presence of CM in T6 plays a key role in this reduction, and verifying its importance in the regulation of the expression of ABA-related genes (Figure 3) in the plant [66,67].

This differential response between inoculation with T34 and T6 could be due to CM encoded by the Tparo7 gene. We have verified that with Tparo7 silenced, Tparo7-S4, loses its ability to increase tolerance against both abiotic stresses in rapeseed, while also ceasing to induce the expression of ABA- and ET-related genes that we can observe in the Tp-TC transformation control and in T6. This indicates the key role of $\mathrm{CM}$ in the induction of these genes and plant abiotic tolerance. Pérez et al. (2015) determined the relationship between CM and T6 biocontrol capacity, as to the prevent the synthesis of secondary metabolites resulting from the shikimate pathway that capacity is reduced [25]. The importance of $\mathrm{CM}$ in the plant response to salinity and drought has been proven in tomato-being involved in the synthesis of crucial aromatic amino acids against stress [58], in Arabidopsis [68], in Musa acuminata [69], and in Salicornia herbacea [70]. In addition, Pérez et al. (2015) observed a bigger production of SA in the transformants with silenced $\mathrm{CM}$, and as this increase in SA levels leads to an increase in the expression of the gene related to ET EIN2 in tomato after root colonization [25]. Under drought and salinity stress, SA increases the activity of antioxidant enzymes that alleviate oxidative stresses; therefore, the role of SA in salt and drought tolerance has been extensively evidenced in many crops [71]. Furthermore, a possible decrease in SA due to the presence of CM could be involved in increasing the tolerance of rapeseed against these abiotic stresses, thanks to the antagonism between SA-ET [72,73] and SA-ABA [74,75]. Therefore, the best response against abiotic stresses observed in rapeseed by inoculation with $\mathrm{T} 6$ and $\mathrm{Tp}-\mathrm{CT}$, through a specific response mediated by ABA and ET against drought and salinity, respectively, could be directly a consequence of a reduction in SA levels by $\mathrm{CM}$, increasing the expression of the antagonist pathway genes.

In conclusion, T. parareesei represents a more efficient alternative than T. harzianum in increasing rapeseed productivity in drought or salinity conditions, probably thanks to a reduction in oxidative stress and the regulation of the expression of hormone genes related to abiotic stresses in the plant. Moreover, CM present in T. parareesei plays a key role in this phyto-fortifying capacity by increasing the expression of genes related to the plant's response to abiotic stresses through the hormonal pathways of ABA and/or ET.

Supplementary Materials: The following are available online at http://www.mdpi.com/2073-4395/10/1/118/s1, Figure S1. Block and sub block random distribution in the greenhouse; Table S1. Table of ANOVA two ways for 
measurements of rapeseed-root colonization by T. harzianum (+T34), T. parareesei $(+\mathrm{T} 6)$, T. parareesei transformation control (+Tp-TC), and the transformant with the silenced Tparo7 gene (+Tparo7-S4) without stress, under drought stress and under salt stress $(\mathrm{NaCl} 200 \mathrm{mM})$.; Table S2. Table of ANOVA two ways for indirect quantification of ROS in roots by relative ion leakage in the roots of rapeseed $(\mathrm{Bn})$ inoculated with T. harzianum (+T34), T. parareesei (+T6), T. parareesei transformation control (+Tp-TC), and the transformants with the silenced Tparo7 gene (+Tparo7-S4).

Acknowledgments: I thank the GIR of the University of Salamanca "Plant Pathology and Biocontrol" for allowing me to use their facilities and the means for the development of this work. I would like to thank Agronomy's reviewers, thanks to whom the document has improved significantly.

Conflicts of Interest: The author declares no conflict of interest.

\section{References}

1. Dresselhaus, T.; Hückelhoven, R. Biotic and Abiotic Stress Responses in Crop Plants. Agronomy 2018, 8, 267. [CrossRef]

2. Gilliham, M.; Able, J.A.; Roy, S.J. Translating knowledge about abiotic stress tolerance to breeding programmes. Plant J. 2017, 90, 898-917. [CrossRef] [PubMed]

3. Pereira, A. Plant abiotic stress challenges from the changing environment. Front. Plant Sci. 2016, 7, 1123. [CrossRef] [PubMed]

4. Zhu, J.K. Abiotic stress signaling and responses in plants. Cell 2016, 167, 313-324. [CrossRef]

5. Thiry, A.A.; Chavez Dulanto, P.N.; Reynolds, M.P.; Davies, W.J. How can we improve crop genotypes to increase stress resilience and productivity in a future climate? A new crop screening method based on productivity and resistance to abiotic stress. J. Exp. Bot. 2016, 67, 5593-5603. [CrossRef] [PubMed]

6. Nuccio, M.L.; Paul, M.; Bate, N.J.; Cohn, J.; Cutler, S.R. Where are the drought tolerant crops? An assessment of more than two decades of plant biotechnology effort in crop improvement. Plant Sci. 2018, 273, 110-119. [CrossRef]

7. Daryanto, S.; Wang, L.; Jacinthe, P.A. Global synthesis of drought effects on food legume production. PLoS ONE 2015, 10, e0127401. [CrossRef]

8. Bulgari, R.; Franzoni, G.; Ferrante, A. Biostimulants application in horticultural crops under abiotic stress conditions. Agronomy 2019, 9, 306. [CrossRef]

9. Munns, R.; Gilliham, M. Salinity tolerance of Crops-What is the cost? New Phytol. 2015, 208, 668-673. [CrossRef]

10. Qiu, Z.; Egidi, E.; Liu, H.; Kaur, S.; Singh, B.K. New frontiers in agriculture productivity: Optimised microbial inoculants and in situ microbiome engineering. Biotechnol. Adv. 2019, 37, 107371. [CrossRef]

11. Van Oosten, M.J.; Pepe, O.; De Pascale, S.; Silletti, S.; Maggio, A. The role of biostimulants and bioeffectors as alleviators of abiotic stress in crop plants. Chem. Biol. Technol. Agric. 2017, 4, 5. [CrossRef]

12. Ma, Y.; Freitas, H.; Vosatka, M. Beneficial microbes alleviate climatic stresses in plants. Front. Plant Sci. 2019, 10, 595. [CrossRef] [PubMed]

13. Lorito, M.; Woo, S.L.; Harman, G.E.; Monte, E. Translational research on Trichoderma: From'omics to the field. Annu. Rev. Phytopathol. 2010, 48, 395-417. [CrossRef] [PubMed]

14. Hermosa, R.; Viterbo, A.; Chet, I.; Monte, E. Plant-beneficial effects of Trichoderma and of its genes. Microbiology 2012, 158, 17-25. [CrossRef] [PubMed]

15. Hermosa, R.; Rubio, M.B.; Cardoza, R.E.; Nicolás, C.; Monte, E.; Gutiérrez, S. The contribution of Trichoderma to balancing the costs of plant growth and defense. Int. Microbiol. 2013, 16, 69-80.

16. Mastouri, F.; Björkman, T.; Harman, G.E. Seed treatment with Trichoderma harzianum alleviates biotic, abiotic, and physiological stresses in germinating seeds and seedlings. Phytopathology 2010, 100, 1213-1221. [CrossRef]

17. Ghorbanpour, A.; Salimi, A.; Ghanbary, M.A.T.; Pirdashti, H.; Dehestani, A. The effect of Trichoderma harzianum in mitigating low temperature stress in tomato (Solanum lycopersicum L.) plants. Sci. Hortic. 2018, 230, 134-141. [CrossRef]

18. Yasmeen, R.; Siddiqui, Z.S. Ameliorative effects of Trichoderma harzianum on monocot crops under hydroponic saline environment. Acta Physiol. Plant. 2018, 40, 4. [CrossRef] 
19. Rubio, M.B.; Hermosa, R.; Vicente, R.; Gómez-Acosta, F.A.; Morcuende, R.; Monte, E.; Bettiol, W. The combination of Trichoderma harzianum and chemical fertilization leads to the deregulation of phytohormone networking, preventing the adaptive responses of tomato plants to salt stress. Front. Plant Sci. 2017, 8, 294. [CrossRef]

20. Sah, S.K.; Reddy, K.R.; Li, J. Abscisic acid and abiotic stress tolerance in crop plants. Front. Plant Sci. 2016, 7, 571. [CrossRef]

21. Kazan, K. Diverse roles of jasmonates and ethylene in abiotic stress tolerance. Trends Plant Sci. 2015, 20, 219-229. [CrossRef] [PubMed]

22. Atanasova, L.; Jaklitsch, W.M.; Komoń-Zelazowska, M.; Kubicek, C.P.; Druzhinina, I.S. Clonal species Trichoderma parareesei sp. nov. likely resembles the ancestor of the cellulase producer Hypocrea jecorina/T. reesei. Appl. Environ. Microbiol. 2010, 76, 7259-7267. [CrossRef] [PubMed]

23. Yang, D.; Pomraning, K.; Kopchinskiy, A.; Aghcheh, R.K.; Atanasova, L.; Chenthamara, K.; Baker, S.E.; Zhang, R.; Shen, Q.; Freitag, M.; et al. Genome sequence and annotation of Trichoderma parareesei, the ancestor of the cellulase producer Trichoderma reesei. Genome Announc. 2015, 3, e00885-15. [CrossRef] [PubMed]

24. Rubio, M.B.; Quijada, N.M.; Pérez, E.; Domínguez, S.; Monte, E.; Hermosa, R. Identifying beneficial qualities of Trichoderma parareesei for plants. Appl. Environ. Microbiol. 2014, 80, 1864-1873. [CrossRef]

25. Pérez, E.; Rubio, M.B.; Cardoza, R.E.; Gutiérrez, S.; Bettiol, W.; Monte, E.; Hermosa, R. The importance of chorismate mutase in the biocontrol potential of Trichoderma parareesei. Front. Microbiol. 2015, 6, 1181. [CrossRef]

26. Friedt, W.; Tu, J.; Fu, T. Academic and economic importance of Brassica napus rapeseed. In The Brassica napus Genome; Springer: Cham, Switzerland, 2018; pp. 1-20. Available online: https://link.springer.com/chapter/10. 1007/978-3-319-43694-4_1 (accessed on 5 November 2019).

27. Montero-Barrientos, M.; Hermosa, R.; Cardoza, R.E.; Gutierrez, S.; Nicolas, C.; Monte, E. Transgenic expression of the Trichoderma harzianum hsp70 gene increases Arabidopsis resistance to heat and other abiotic stresses. J. Plant Physiol. 2010, 167, 659-665. [CrossRef]

28. Poveda, J.; Hermosa, R.; Monte, E.; Nicolás, C. Trichoderma harzianum favours the access of arbuscular mycorrhizal fungi to non-host Brassicaceae roots and increases plant productivity. Sci. Rep. 2019, 9, 1-11. [CrossRef]

29. Poveda, J.; Hermosa, R.; Monte, E.; Nicolas, C. The Trichoderma harzianum Kelch protein ThKEL1 plays a key role in root colonization and the induction of systemic defense in Brassicaceae plants. Front. Plant Sci. 2019, 10, 1478. [CrossRef]

30. Chen, Y.; Lei, S.; Zhou, Z.; Zeng, F.; Yi, B.; Wen, J.; Shen, J.; Ma, C.; Tu, J.; Fu, T. Analysis of gene expression profile in pollen development of recessive genic male sterile Brassica napus L. line S45A. Plant Cell Rep. 2009, 28, 1363-1372. [CrossRef]

31. Du, C.; Hu, K.; Xian, S.; Liu, C.; Fan, J.; Tu, J.; Fu, T. Dynamic transcriptome analysis reveals AP2/ERF transcription factors responsible for cold stress in rapeseed (Brassica napus L.). Mol. Genet. Genom. 2016, 291, 1053-1067. [CrossRef]

32. Xu, P.; Cai, W. Functional characterization of the BnNCED3 gene in Brassica napus. Plant Sci. 2017, 256, 16-24. [CrossRef] [PubMed]

33. Di, F.; Jian, H.; Wang, T.; Chen, X.; Ding, Y.; Du, H.; Lu, K.; Li, J.; Liu, L. Genome-wide analysis of the PYL gene family and identification of PYL genes that respond to abiotic stress in Brassica napus. Genes 2018, 9, 156. [CrossRef] [PubMed]

34. Livak, K.J.; Schmittgen, T.D. Analysis of relative gene expression data using real-time quantitative PCR and the $2^{-\Delta \Delta C T}$ method. Methods 2001, 25, 402-408. [CrossRef]

35. Aguilar, E.; Almendral, D.; Allende, L.; Pacheco, R.; Chung, B.N.; Canto, T.; Tenllado, F. The P25 protein of Potato virus $\mathrm{X}$ (PVX) is the main pathogenicity determinant responsible for systemic necrosis in PVX-associated synergisms. J. Virol. 2015, 89, 2090-2103. [CrossRef] [PubMed]

36. Mondo, J.M.; Kimani, P.M.; Narla, R.D. Genotype x Environment Interactions on Seed Yield of Inter-racial Common Bean Lines in Kenya. World J. Agric. Res. 2019, 7, 76-87. [CrossRef]

37. Soltani, E.; Adeli, R.; Akbari, G.A.; Ramshini, H. Application of hydrotime model to predict early vigour of rapeseed (Brassica napus L.) under abiotic stresses. Acta Physiol. Plant. 2017, 39, 252. [CrossRef]

38. Wang, J.; Jiao, J.; Zhou, M.; Jin, Z.; Yu, Y.; Liang, M. Physiological and Transcriptional Responses of Industrial Rapeseed (Brassica napus) Seedlings to Drought and Salinity Stress. Int. J. Mol. Sci. 2019, 20, 5604. [CrossRef] 
39. Yang, H.; Deng, L.; Liu, H.; Fan, S.; Hua, W.; Liu, J. Overexpression of BnaAOX1b Confers Tolerance to Osmotic and Salt Stress in Rapeseed. G3 2019, 9, 3501-3511. [CrossRef]

40. Santangeli, M.; Capo, C.; Beninati, S.; Pietrini, F.; Forni, C. Gradual Exposure to Salinity Improves Tolerance to Salt Stress in Rapeseed (Brassica napus L.). Water 2019, 11, 1667. [CrossRef]

41. Khan, M.N.; Zhang, J.; Luo, T.; Liu, J.; Rizwan, M.; Fahad, S.; Xu, Z.; Hu, L. Seed priming with melatonin coping drought stress in rapeseed by regulating reactive oxygen species detoxification: Antioxidant defense system, osmotic adjustment, stomatal traits and chloroplast ultrastructure perseveration. Ind. Crop. Prod. 2019, 140, 111597. [CrossRef]

42. Zhu, B.; Xu, Q.; Zou, Y.; Ma, S.; Zhang, X.; Xie, X.; Wang, L. Effect of potassium deficiency on growth, antioxidants, ionome and metabolism in rapeseed under drought stress. Plant Growth Regul. 2019, 1-12. [CrossRef]

43. Kowalska, J. Organically grown Brassica napus-Use of border strips and Trichoderma. Soil Plant Sci. 2014, 64, 529-536.

44. Znajewska, Z.; Dabrowska, G.B.; Narbutt, O. Trichoderma viride strains stimulating the growth and development of winter rapeseed (Brassica napus L.). Prog. Plant Prot. 2018, 58. [CrossRef]

45. Maag, D.; Kandula, D.R.; Müller, C.; Mendoza-Mendoza, A.; Wratten, S.D.; Stewart, A.; Rostás, M. Trichoderma atroviride LU132 promotes plant growth but not induced systemic resistance to Plutella xylostella in oilseed rape. Biol. Control 2014, 59, 241-252. [CrossRef]

46. Alkooranee, J.T.; Aledan, T.R.; Ali, A.K.; Lu, G.; Zhang, X.; Wu, J.; Fu, C.; Li, M. Detecting the hormonal pathways in oilseed rape behind induced systemic resistance by Trichoderma harzianum TH12 to Sclerotinia sclerotiorum. PLOS ONE 2017, 12, e0168850. [CrossRef]

47. Alkooranee, J.T.; Yin, Y.; Aledan, T.R.; Jiang, Y.; Lu, G.; Wu, J.; Li, M. Systemic Resistance to Powdery Mildew in Brassica napus (AACC) and Raphanus alboglabra (RRCC) by Trichoderma harzianum TH12. PLoS ONE 2015, 10, e0142177. [CrossRef]

48. Baysal-Gurel, F.; Liyanapathiranage, P.; Mullican, J. Biofumigation: Opportunities and challenges for control of soilborne diseases in nursery production. Plant Health Prog. 2018, 19, 332-337. [CrossRef]

49. Nafees, M.; Ali, S.; Naveed, M.; Rizwan, M. Efficiency of biogas slurry and Burkholderia phytofirmans PsJN to improve growth, physiology, and antioxidant activity of Brassica napus L. in chromium-contaminated soil. Environ. Sci. Pollut. Res. 2018, 25, 6387-6397. [CrossRef]

50. Li, H.; Lei, P.; Pang, X.; Li, S.; Xu, H.; Xu, Z.; Feng, X. Enhanced tolerance to salt stress in canola (Brassica napus L.) seedlings inoculated with the halotolerant Enterobacter cloacae HSNJ4. Appl. Soil Ecol. 2017, 119, 26-34. [CrossRef]

51. Szymańska, S.; Dąbrowska, G.B.; Tyburski, J.; Niedojadło, K.; Piernik, A.; Hrynkiewicz, K. Boosting the Brassica napus L. tolerance to salinity by the halotolerant strain Pseudomonas stutzeri ISE12. Environ. Exp. Bot. 2019, 163, 55-68. [CrossRef]

52. Zhang, F.; Wang, Y.; Liu, C.; Chen, F.; Ge, H.; Tian, F.; Yang, T.; Ma, K.; Zhang, Y. Trichoderma harzianum mitigates salt stress in cucumber via multiple responses. Ecotoxicol. Environ. Saf. 2019, 170, 436-445. [CrossRef] [PubMed]

53. Zhang, S.; Gan, Y.; Xu, B. Application of plant-growth-promoting fungi Trichoderma longibrachiatum T6 enhances tolerance of wheat to salt stress through improvement of antioxidative defense system and gene expression. Front. Plant Sci. 2016, 7, 1405. [CrossRef] [PubMed]

54. Zhang, S.; Gan, Y.; Xu, B. Mechanisms of the IAA and ACC-deaminase producing strain of Trichoderma longibrachiatum T6 in enhancing wheat seedling tolerance to $\mathrm{NaCl}$ stress. BMC Plant Biol. 2019, 19, 22. [CrossRef] [PubMed]

55. Mona, S.A.; Hashem, A.; Abd_Allah, E.F.; Alqarawi, A.A.; Soliman, D.W.K.; Wirth, S.; Egamberdieva, D. Increased resistance of drought by Trichoderma harzianum fungal treatment correlates with increased secondary metabolites and proline content. J. Integr. Agric. 2017, 16, 1751-1757. [CrossRef]

56. Khoshmanzar, E.; Aliasgharzad, N.; Neyshabouri, M.R.; Khoshru, B.; Arzanlou, M.; Lajayer, B.A. Effects of Trichoderma isolates on tomato growth and inducing its tolerance to water-deficit stress. Int. J. Environ. Sci. Technol. 2019, 1-10. [CrossRef]

57. Brotman, Y.; Landau, U.; Cuadros-Inostroza, A.; Takayuki, T.; Fernie, A.R.; Chet, I.; Viterbo, A.; Willmitzer, L. Trichoderma-plant root colonization: Escaping early plant defense responses and activation of the antioxidant machinery for saline stress tolerance. PLoS Pathog. 2013, 9, e1003221. [CrossRef] 
58. Filiz, E.; Cetin, D.; Akbudak, M.A. Aromatic amino acids biosynthesis genes identification and expression analysis under salt and drought stresses in Solanum lycopersicum L. Sci. Hortic. 2019, 250, 127-137. [CrossRef]

59. Chikkaputtaiah, C.; Debbarma, J.; Baruah, I.; Havlickova, L.; Boruah, H.P.D.; Curn, V. Molecular genetics and functional genomics of abiotic stress-responsive genes in oilseed rape (Brassica napus L.): A review of recent advances and future. Plant Biotechnol. Rep. 2017, 11, 365-384. [CrossRef]

60. Wani, S.H.; Kumar, V.; Shriram, V.; Sah, S.K. Phytohormones and their metabolic engineering for abiotic stress tolerance in crop plants. Crop J. 2016, 4, 162-176. [CrossRef]

61. Zhuang, J.; Xiong, A.S.; Peng, R.H.; Gao, F.; Zhu, B.; Zhang, J.; Fu, X.Y.; Jin, X.F.; Chen, J.M.; Zhang, Z.; et al. Analysis of Brassica rapa ESTs: Gene discovery and expression patterns of AP2/ERF family genes. Mol. Biol. Rep. 2010, 37, 2485-2492. [CrossRef]

62. Zhang, F.; Zhang, J.; Chen, L.; Shi, X.; Lui, Z.; Li, C. Heterologous expression of ACC deaminase from Trichoderma asperellum improves the growth performance of Arabidopsis thaliana under normal and salt stress conditions. Plant Physiol. Biochem. 2015, 94, 41-47. [CrossRef]

63. Contreras-Cornejo, H.A.; Macías-Rodríguez, L.; Alfaro-Cuevas, R.; López-Bucio, J. Trichoderma spp. improve growth of Arabidopsis seedlings under salt stress through enhanced root development, osmolite production, and Na+ elimination through root exudates. Mol. Plant-Microbe Interact. 2014, 27, 503-514. [CrossRef] [PubMed]

64. Gill, S.S.; Tuteja, N. Reactive oxygen species and antioxidant machinery in abiotic stress tolerance in crop plants. Plant Physiol. Biochem. 2010, 48, 909-930. [CrossRef] [PubMed]

65. Petrov, V.; Hille, J.; Mueller-Roeber, B.; Gechev, T.S. ROS-mediated abiotic stress-induced programmed cell death in plants. Front. Plant Sci. 2015, 6, 69. [CrossRef] [PubMed]

66. You, J.; Chan, Z. ROS regulation during abiotic stress responses in crop plants. Front. Plant Sci. 2015, 6, 1092. [CrossRef] [PubMed]

67. Choudhury, F.K.; Rivero, R.M.; Blumwald, E.; Mittler, R. Reactive oxygen species, abiotic stress and stress combination. Plant J. 2017, 90, 856-867. [CrossRef]

68. Böttcher, C.; Chapman, A.; Fellermeier, F.; Choudhary, M.; Scheel, D.; Glawischnig, E. The biosynthetic pathway of indole-3-carbaldehyde and indole-3-carboxylic acid derivatives in Arabidopsis. Plant Physiol. 2014, 165, 841-853. [CrossRef]

69. Lee, W.S.; Gudimella, R.; Wong, G.R.; Tammi, M.T.; Khalid, N.; Harikrishna, J.A. Transcripts and microRNAs responding to salt stress in Musa acuminata Colla (AAA Group) cv. Berangan roots. PLoS ONE 2015, 10, e0127526. [CrossRef]

70. Lee, S.J.; Jeong, E.M.; Ki, A.Y.; Oh, K.S.; Kwon, J.; Jeong, J.H.; Chung, N.J. Oxidative defense metabolites induced by salinity stress in roots of Salicornia herbacea. J. Plant Physiol. 2016, 206, 133-142. [CrossRef]

71. Khan, M.I.R.; Fatma, M.; Per, T.S.; Anjum, N.A.; Khan, N.A. Salicylic acid-induced abiotic stress tolerance and underlying mechanisms in plants. Front. Plant Sci. 2015, 6, 462. [CrossRef]

72. Martinez, C.; Blanc, F.; Le Claire, E.; Besnard, O.; Nicole, M.; Baccou, J.C. Salicylic acid and ethylene pathways are differentially activated in melon cotyledons by active or heat-denatured cellulase from Trichoderma longibrachiatum. Plant Physiol. 2001, 127, 334-344. [CrossRef] [PubMed]

73. Zander, M.; Thurow, C.; Gatz, C. TGA transcription factors activate the salicylic acid-suppressible branch of the ethylene-induced defense program by regulating ORA59 expression. Plant Physiol. 2014, 165, 1671-1683. [CrossRef] [PubMed]

74. de Torres Zabala, M.; Bennett, M.H.; Truman, W.H.; Grant, M.R. Antagonism between salicylic and abscisic acid reflects early host-pathogen conflict and moulds plant defence responses. Plant J. 2009, 59, 375-386. [CrossRef] [PubMed]

75. Moeder, W.; Ung, H.; Mosher, S.; Yoshioka, K. SA-ABA antagonism in defense responses. Plant Signal. Behav. 2010, 5, 1231-1233. [CrossRef] [PubMed]

(C) 2020 by the author. Licensee MDPI, Basel, Switzerland. This article is an open access article distributed under the terms and conditions of the Creative Commons Attribution (CC BY) license (http://creativecommons.org/licenses/by/4.0/). 